\title{
A STUDY ON CULTURAL REPRESENTATION OF WOMEN IN TAMIL FILMS
}

\section{DR. R. PREETHA}

Assistant Professor, Department of Electronic Media, M.O.P Vaishnav College for Women,

Chennai, Tamil Nadu, India

\begin{abstract}
India is a country of diverse culture varying from region to region with different linguistic patterns. Indian films have frequently encountered globalized forms of cultural expression. Globalization made drastic changes in the Indian media industry. Regional films like Tamil movies play a significant and unique role in creating an impact on culture especially in shaping the society. Tamil movies were appreciated as the best movies by experts and by their regional people. Representation and portrayal of women in Tamil films changed dramatically in the last few years and have created a big impact. The study aims and explores at analyzing women's role in Tamil film and the emerging trends by how women is been represented in films creating an impact on various cultural factors like local culture, image portrayed, career, family relationships, education, decision making. The study uses qualitative method of research design to critically examine and analyze the cultural representation of women in Tamil films through in depth interviews.
\end{abstract}

KEYWORDS: Tamil Films, Cultural Representation \& Construction of Images

Received: Jan 22, 2019; Accepted: Feb 12, 2019; Published: May 22, 2019; Paper Id.: IJCMSJUN201915

\section{INTRODUCTION}

In the journey of hundred years, Indian cinema has come a long way so the portrayal of women characters. Representation of women has evolved in a different way across the globe with respect to the Film industry. Women mostly represent enhancing roles in Indian cinema, especially in Tamil films for a long period. Representation of women in the mass media not only touched the lives of the audience, but also showed their inner strength, beauty and complexity. Each decade has presented its own brand of women.

Women's position within the media power structures and media representations of women are persistently concerned in every society because negative stereotyping reflects and reinforce wider gender inequalities. Tamil films maintain the transmission of traditional women's roles depicting culture and society. Research on gender and cinema has emphasized the question about women's identity. In fact, the study of the images of women in cinema were a central concern of the 'second wave' feminism of the 1960s and 1970s, criticizing women's image in film and women's roles in the film industry Jackson and Jacjie (1998).

In developing countries like India, cinema forms a part of the social, economic, and political context, it holds a strategic importance as a cultural phenomenon, which obviously takes into account the rapid development in the production and consumption of cultural products Thomas, (2001)

Mythology, religion, notions and ideas about family, tradition and cultural values strongly influence Tamil film industry. Though Tamil movies is still ruled and dominated by the premise of patriarchy, an emerging 
trend is breaking this barrier. Tamil cinema helped to articulate the political and cultural ideology through various signs and symbols. Cultural narratives in Tamil films reflect the sentiments and aspirations of Tamil people. The cinema industry takes special care to construct the social, cultural, and political values of society.

\section{REVIEW OF LITERATURE}

Cinema a popular medium of entertainment is now more than a century old. Comparatively only recently has society realized cinema is the great potential as an instrument of entertainment, instruction, motivation, and construction. Developing countries in their effort to accelerate the processes of economic and social change have taken this popular medium as their best means of supplementing or replacing the traditional communication forms. Even with the arrival of Radio and Television, Satellite and Internet communication, the crucial role of cinema and its myriad possibilities in social change and development have still to be explored Hopkinson, (1971). The whole world identifies with the cinema and thus it becomes a universal medium. The truth is that the global community is aware of and accepts the influence and impact of cinema on the society, Subramanian (1990)

'Mother India' movie signifies a strong political statement on a woman who can do anything to establish justice within the framework of marriage and motherhood. She defies a micro state of being a biological mother in order to fit in the framework of being the mother of the nation. This film created such a huge impact that people started to cast women as main characters in movies in the following decades.

Mass communication in general accelerates and expands the spread of knowledge in the developing world and cinema has an important role as it increases the speed in social development and change. Cinema teaches new desires and satisfaction, new morality and ethics, devotion and worship, new paths and means of attaining power. It portrays role models particularly for children and youth to imitate (David, 1983, p. 2).

Cinema represents a social and historical practice regarding gender approach. It can also be said that the media is crucial in the construction of gender ideologies socialization. Media culture provides a sense of selfhood, construction of ethnicity, race and nationality, Dines and Humez (2003). Film is the term most commonly used mass media to communicate with the public.

Understanding the function of art and technology in a given cultural environment is very important because people are conditioned by the cultural environment, and the cultural environment comes from the media network, Youngblood (1970)

The film is one of the major means of communication to reach a wider audience. Of all the media, cinema plays the best role to convey the message to its viewers with its audio-visual and representational qualities. Either to critique a social system or to praise a cultural system, the cinema can always do wonders in spearheading the change. The cinema acts as an alternative public sphere providing space for multiple sections of the society to represent and assert one's identity. People imitate, imagine and compare themselves with the characters playing in the celluloid. The visual narrative of the cinema represents the people's choices, lives and their identities, Shiva Thrishul Punyamurthy.

Cultural identities, the core of Tamil society are the family. The family plays a significant role in the transmission of traditions. Families in turn join to form clans, castes, and communities. Cultural traits had been handed over across generations through the channel of family using dance, music, drama, other performing arts, Reddy (1989) 
Regional cinema has its own identity due to its unique characteristics and qualities by which we can understand through local culture. Regional cinema's structure is formed on the base of local culture and custom. Regional films assimilate these elements in their portrayal through marriage, dowry, caste, ritual performed for gods and goddess. The depiction of these elements attracts more people towards regional movies due to its local colour and touch. Regional movies have strong appealing power to express social issues. Therefore, we can say that regional cinema has strong appealing power to express the culture, custom and ritual of a particular region, Subhash Chandra Bose.

The cultural context in Tamil Nadu is marked by unequal relations that are rooted in centuries old religious scriptures, customs, and social norms. This unequal treatment can be seen as various forms of discrimination based on caste and gender, including domestic violence against women. Women play a minimal role in the family which is the basic societal unit with prescribed traditional roles for everyone, Panchanadeswaran \& Koverola (2005)

Tamil Cinema: A cultural outlook As Tamil cinema developed it looked mostly the social orientated themes that were deeply rooted in the Tamil language and culture. "When the trend turned towards entertainment and commercial Tamil cinema offers a visual commentary in the form of popular culture entangled directly with the lives of the people so as to enable them to consume various information, belief systems, and cultural commodities and thus fulfil social and cultural needs" (Jesudoss, 2009).

Tamil Cinema: A cultural outlook As Tamil cinema developed it looked mostly the social orientated themes that were deeplyrooted in the Tamil language and culture. "When the trend turned towards entertainment and commercial Tamil cinema offers a visual commentary in the form of popular culture entangled directly with the lives of the people so as to enable them to consume various information, belief systems, and cultural commodities and thus fulfil social and cultural needs" (Jesudoss, 2009).

Tamil Cinema: A cultural outlook As Tamil cinema developed it looked mostly the social orientated themes that were deeply rooted in the Tamil language and culture. "When the trend turned towards entertainment and commercial Tamil cinema offers a visual commentary in the form of popular culture entangled directly with the lives of the people so as to enable them to consume various information, belief systems, and cultural commodities and thus fulfil social and cultural needs" (Jesudoss, 2009).

Tamil Cinema: A cultural outlook As Tamil cinema developed it looked mostly the social orientated themes that were deeply rooted in the Tamil language and culture. "When the trend turned towards entertainment and commercial Tamil cinema offers a visual commentary in the form of popular culture entangled directly with the lives of the people so as to enable them to consume various information, belief systems, and cultural commodities and thus fulfil social and cultural needs" (Jesudoss, 2009).

The rise of feminist ideas has led to the tremendous improvement of women's condition throughout the world in recent times. Access to education has been one of the most pressing demands of theses women's rights movements. Education is a potent tool in the emancipation and empowerment of women, the greatest single factor which can incredibly improve the status of women in any society. Education enables women not only to gain more knowledge about the world outside and home but helps her to get status, positive self esteem, and self-confidence, necessary courage and inner strength to face challenges in life that social structure throws at her. 
In most society's males are given more importance towards decisions in the family and in the society. In the family as well as in the society the decision making power is denied to women making women voiceless, destroying their self-confidence by making them feel less important in the family as well as in the society. In India large percentage of women do not have decision making power. They cannot make decisions independently, not even related to their own life be it any issue related to education, marriage, or their children. Autonomy is the ability to obtain information and make decisions about one's own concerns. It facilitates access to material resources such as food, land, income and other forms of wealth, and social resources such as knowledge, power, prestige within the family and community (Acharya et al., 2010). Limitations to women's physical, sexual, economic, social and political autonomy may affect women's decision-making processes. On the contrary if the women attain this autonomy, it becomes a source of their empowerment.

Over the years, we have seen women characters in Tamil films growing from households to the working class, business women, engineers, artists, IT professionals, sportswoman and many more in the field of cinema. Most of the Tamil movies directed recently portray women as central characters with strong female centric plots. Tamil Films have influenced the way in which people perceive various aspects connecting with their own lives.

\section{OBJECTIVES OF THE STUDY}

- To study the representations of the characters portrayed by women in Tamil cinema

- To identify the roles and cultural values represented by women in Tamil cinema.

\section{METHODOLOGY}

An exploratory study was done to understand the cultural representation of women in Tamil films, also their representation of cultural values depicted in the big screen. The selected sample size for the study was 20 respondents. The sample selected for the study was women from age group 25 to 35 years across Chennai. Data was collected through in depth interview method for further understanding the view of the respondents.

They respondents answered to questions on Auteur structuralism, Male dominance, Colourism, Women Empowerment, Employment, Career choices and Livelihood patterns. Among 20 respondents, 10 of them were selected for the study. Invites and constant reminders were sent to 10 respondents. Finally 10 respondents were selected by convenient sampling process and interviewed to obtain the results. Interviews were conducted in person coded and then recorded. The interview questions were designed based on the expert opinion.

\section{FINDINGS AND ANALYSIS}

The researcher was able to identify outcomes related to questions that attracted the respondents through in depth interviews. The respondents reported about cultural representations depicted in the selected films, the roles portrayed by actress that related to any women in day today life.

\section{Representation of Women in Movies}

Following are the analysis collected from the Respondent 1, 2, 6 and 11

R 1: Karuthamma a village story plot directed by Bharathiraja in 1994. The movie was set in a rural village portraying local dialect playing a prominent role in regional movies. The movie clearly outlines in identifying three strong powerful women characters of Rajshree, Saranya and Maheshwari in villages. The movie focuses elements like female infanticide, sentiments, emotions, local culture, dowry, male dominance, liability to bring in male heirs and financial crisis 
caused because of girl child. When a girl child is born she is considered as a curse and not a blessing. Our culture has deep rooted in telling that when a girl child is born she is considered to be goddess. In this movie once the girl child grows she is considered to be more of burden than of bliss. The plot highlights on illiteracy the key factor, an obstacle which constraints women to be dependent on men due to economic reasons.

R2: Manathil Urudhi Vendum movie directed by veteran director K. Balachander (1987) starring Suhasini in the lead role where she shoulders the entire fate of her family and live only for them. She plays the role of a nurse and is portrayed as the sole bread winner for her family. At a time when the Tamil cinema industry was characterized by movies that focused on glorifying just the hero, this movie clearly shows how women face challenges in the male dominated society. It is not a hero centric movie and the traits of the actress represent to be a fighter, independent, career and goal oriented. She compromises her personal interests for the sake of the family. The concept of the family plays a significant role in the transmission of traditions. He gave a new identity to the heroine and revamped her role through his movies, which majorly centered on women and their struggles. The requirements to the subject of marriage, being married, the performing roles and functions of a woman adhering to the rules of the family were central themes in Tamil films. Also employment is considered to be a key factor in which Suhasini is portrayed as self reliant and strong independent women boosting her self confidence through her profession.

R6: Kalyana Agathigal movie (1985) by K Balachander caution women to be alert of their own security after marriage. The story revolves around seven women who suffer after marriage. The story points out that education and job opportunities will only lead to a better life. Employment is always considered as a key factor for women to protect themselves. Each woman is identified with varied profession like typist, nurse, teacher and many more. Tamil cinema still perpetuates conventional gender stereotypes because it reflects dominant social values. Stereotypes of male dominance and feminine surrender is portrayed, justified and challenged in this film. The plot highlights on Women empowerment.

R11: Oru Veedu Iru Vasal (1990) in which the story spins around two distinct story lines with lead female roles namely Vaishnavi and Yamini. In the first half it's about a musician cheating his housemaid inspite of getting married and cheats her as she is an illiterate. It shows the women's difficulties and how marriages are performed in the male dominated society. Both women are given distinct story lines in which they had to face the struggles because of men and their dominance.

\section{Cultural Portrayal of Women in Movies}

The two respondents R 5 and 10 gave an overall view of cultural variables used by directors, actors and actress.

R5: Colourism plays an important cultural factor in Tamil Cinema and was prevalent in ancient India. The credit for choosing heroines only for their performance and their skin tone actually goes to veteran directors $\mathrm{K}$ Balachander and Balumahendra who gave ample scope to dark complexioned heroines like Shobha in Mullum Malarum, Sarita in Achamillai Achamillai, Sujatha in Avargal and Archana in Veedu. Dark skinned female lead actresses in Tamil movies are always seen as a symbol of beauty and intelligence. Skin tone is normally associated and deeply attached with value systems and culture.

R10: Female comedians have also emerged through the decades and dominated the Tamil film industry. But the development of portrayal of female comedians has shown tremendous escalation in the 80s and 90s. Female comedians would undergo physical abuse in the name of comedy and that probably did not strike to us as wrong portrayal. An 
extremely popular comedian Vadivelu would physically abuse Kovai Sarala another popular female comedian, who plays as subordinate role upholding family values, taking care of children, performing role of a perfect mother, daughter in law. The concept of being a housewife or the male dominance of a family and verbal abuse was very evident in their movies.

Thus it is revealed that depiction of dowry, female infanticide, verbal abuse, illiteracy, career choices, power of education given to women are being portrayed in Tamil Films over the period of years. Further, in conservative society old traditions, customs and values remain the same. Films are the mirrors of our life. Those roles which are done by heroines are much spoken because they turn out to be real and be connected to real life of the audience. They are also encouraged mentally and can handle the society even more tactfully.

\section{CONCLUSIONS}

Films have become an important communication tool in the last few years. The findings of the study elucidate that from the in depth interview analysis conducted, it is clearly seen that in changing times and decades, portrayal of women has definitely evolved through the years but it is yet to catch the progress of our society. All the above mentioned movies bring to light the strong cultural perception values towards woman centric roles The roles portrayed by the lead heroines are the day to day problems faced by woman in our society. The respondents were able to relate and connect themselves. The study emphasizes the fact that cultural values depicted in films prove to be influential in shaping women's identity. Films reflect society's ideas, beliefs and culture. Therefore, a nation such as India should be proud of its growing value in Filmmaking.

\section{REFERENCES}

1. Acharya D. R., Bell J.S., Simkhada P., Van Teijlingen E.R., and Regmi P.R. (2010) Women's Autonomy in Household Decision-Making: A Demographic Study in Nepal.

2. David, C. R. W. (1983) Cinema as medium of communication in TamilNadu, Madras: Christian Literature Society

3. Dines, G. and Humez, J.M. (2003) Gender, Race and Class in Media. London: Sage Publications.

4. Hopkinson, P. (1971). The Role of Film Development. Paris: UNESCO.

5. Jackson S, and Jacjie J. (1998). Contemporary Feminist Theories. Edinburgh: Edinburgh University Press.

6. Reddy, U. (1989). Media and culture in Indian society: Conflict or co-operation? Media, Culture \& Society, 11(4), 395-413.

7. Panchanadeswaran, S., \& Koverola, C. (2005). The voices of battered women in India. Violence Against Women,

8. Subhash Chandra Bose. Women in Regionsl Languages. Retrieved from

9. epgp.inflibnet.ac.in/.../women_studies/gender_studies/...women...films/...women...film

10. Priya, S., \& Bhatiya, P. (2014). The Impact Of Unconventional Media On Rural Masses. Senior Lecturer \& Professor and Head, Department of MBA, Babu Banarsi Das National Institute of Technology and Management, Lucknow, 2(2), 23-32.

11. Subramanian, S. (1990). Cinema Sila Paarvaigal: [Articles on films]. Madras: Tamil

12. Puthakalayam Shiva Thrishul Punyamurthy. Amity Journal of Media \& Communication Studies (ISSN 2231 - 1033$) 2016$ Vol. 6, No. 2 Interpreting the Representational Meanings of a Movie from a Subaltern Perspective

13. Thomas, P. N. (2001). The Political Economy of Communications in India.

14. Youngblood, G. (1970). Expanded Cinema. New York: P. Dutton \& Co. Inc. 